IZA DP No. 7970

Why Is There No Income Gap Between the Hui Muslim Minority and the Han Majority in Rural Ningxia, China?

Björn Gustafsson

Ding Sai

February 2014 


\title{
Why Is There No Income Gap Between the Hui Muslim Minority and the Han Majority in Rural Ningxia, China?
}

\author{
Björn Gustafsson \\ Göteborg University \\ and IZA \\ Ding Sai \\ Chinese Academy of Social Sciences
}

Discussion Paper No. 7970

February 2014

\author{
IZA \\ P.O. Box 7240 \\ 53072 Bonn \\ Germany \\ Phone: +49-228-3894-0 \\ Fax: +49-228-3894-180 \\ E-mail: iza@iza.org
}

Any opinions expressed here are those of the author(s) and not those of IZA. Research published in this series may include views on policy, but the institute itself takes no institutional policy positions. The IZA research network is committed to the IZA Guiding Principles of Research Integrity.

The Institute for the Study of Labor (IZA) in Bonn is a local and virtual international research center and a place of communication between science, politics and business. IZA is an independent nonprofit organization supported by Deutsche Post Foundation. The center is associated with the University of Bonn and offers a stimulating research environment through its international network, workshops and conferences, data service, project support, research visits and doctoral program. IZA engages in (i) original and internationally competitive research in all fields of labor economics, (ii) development of policy concepts, and (iii) dissemination of research results and concepts to the interested public.

IZA Discussion Papers often represent preliminary work and are circulated to encourage discussion. Citation of such a paper should account for its provisional character. A revised version may be available directly from the author. 
IZA Discussion Paper No. 7970

February 2014

\section{ABSTRACT}

\section{Why Is There No Income Gap Between the Hui Muslim Minority and the Han Majority in Rural Ningxia, China?*}

Using a household sample survey for 2006 we show that the Hui population in the rural part of Ningxia autonomous region of China is disadvantaged compared to the Han majority as regards length of education and household per capita wealth. Yet there is no gap in average disposable income between the two ethnic groups and poverty rates are very similar. This paradox is due to members of Hui households earning more income outside the farm than members of Han households. Particularly young male Hui living in poor villages have a remarkably high likelihood of migrating, thereby bringing home income to their households.

JEL Classification: D31, J15, R23

Keywords: China, ethnic minorities, Hui ethnicity, income, poverty, migration

Corresponding author:

Björn Gustafsson

Department of Social Work

Göteborg University

P.O. Box 720

40530 Göteborg

Sweden

E-mail: Bjorn.Gustafsson@socwork.gu.se

\footnotetext{
* Forthcoming in China Quarterly. This research was supported by a grant from the Swedish agency for Development Cooperation, Sida. The survey we analysed was funded by the Neiwa Nakajina Foundation, Japan and Hitotsubashi University, Tokyo (Need-based Area studies project and Global COE project). We are grateful for comments received when presenting earlier versions of the paper at the workshop "Economic and Society Development in China and the World", Institute of Ethnology and Anthropology, Chinese Academy of Social Sciences, Beijing, P.R. China, October 13 and 14, 2011, and the $32^{\text {nd }}$ General Conference of the International Association for Research on Income and Wealth (IARIW), August 5-11, 2012, Boston, U.S.A.
} 


\section{Introduction}

In China, public policy has stressed equality between ethnic groups. China's 55 officially recognised national minorities (Minzu) are unequally distributed over the country. An important part of the policy is the system of regional autonomy which consists of intersecting territories. The largest autonomous areas are the five autonomous regions (zizhi qu): Tibet, Xinjiang, Guangxi, Ningxia and Inner Mongolia. Ethnic regional autonomy has several dimensions: cultural, allowing official use of the minority language, for example, as well as social, by promoting minority persons to become cadre and take part in policymaking and policy implementation. Ethnic regional autonomy also has an economic dimension by the provision of special funding to the autonomous areas.

In each of the autonomous regions there are minority persons as well as members of the Han majority, although the proportions vary across regions. In Tibet and Xinjiang, minority persons are in the majority while they are in the minority in the other three regions. Clearly it should be of great interest to know if and to what extent there are ethnic income and poverty disparities within the autonomous regions. Are the minorities masters in their home regions, or are they at a disadvantage compared to the Han majority also living there? The existence of an income gap can foster social tensions. However, there seems to be no study investigating the question, which provides one motivation for this paper.

Here we focus on the rural part of Ningxia Hui autonomous region and compare the Hui minority to the Han majority with an emphasis on household income and poverty. Ningxia Hui autonomous region, located in northwest China has a population of slightly more than six million persons of whom approximately one-third are Hui and two-thirds belong to the Han 
majority. The Hui and the Han have language and physical appearance in common and yet they differ, as the Hui are Muslims and historically have their own identity. Differences between the Hui and Han are visible in religious practice, diet, dress and often name. As we will show using a unique sample survey for circumstances in 2006, the two populations are rather separated from each other when it comes to marriage and to a somewhat lesser extent to friendship.

Muslim minorities of considerable size are found in other countries, as well. For example, rich countries in northern Europe are now home to a large number of Muslim persons due to recent immigration. A particularly worrisome situation is illustrated in results from the latest research which indicates that such Muslim minorities are economically disadvantaged compared to the majority population of the country where they live. This has been shown to be the case in Britain (Georgladis and Manning, 2011) as well as in Germany (Buechel and Frick, 2004). In India, too, the Muslim minority is in an economically disfavoured situation in many aspects compared to the Hindu majority (Basant and Shafiff, 2010). Therefore results from this study comparing the Hui and Han in rural Ningxia should not only be of importance for those interested in Chinese circumstances. We are actually addressing the following question: To what extent are there gaps in income and poverty in a location where Muslims have lived for many generations? This is the second motivation for our study.

This study shows that the Hui are disadvantaged both in terms of length of education and possession of household wealth within the region in which they are supposed to have a special position. However, a central result is that there is no divide between Hui and Han in rural Ningxia regarding average household income and poverty when the latter is estimated using poverty lines applied by the National Bureau of Statistics for the same year. This paradox can 
be explained by the Hui earning more income outside the farm. In particular, young male Hui living in poor villages have a remarkably high likelihood of migrating, thereby bringing home income to their households. We are not aware of any previous study on an ethnic minority in China in which such a mechanism has been shown.

The rest of the paper is laid out as follows: In Section 2 we survey the literature on ethnic disparities in household income and poverty in China. Section 3 presents some facts on the Ningxia autonomous region and the Hui ethnic group. The survey we work with is introduced in Section 4. Some key facts on the two ethnic groups including length of education and household wealth are presented in Section 5. Section 6 compares household income and poverty for the two ethnic groups. The same section also investigates factors that determine household income and rural migration in order to better understand the lack of difference in mean household income and the extent of poverty across the two ethic groups. Finally we sum up the findings in the concluding section.

\section{Ethnic income disparities in rural China according to previous research}

As the result of a historical process, the People's Republic of China now officially defines ethnic minority people as those persons belonging to one of 55 recognised ethnic minorities and not the Han majority. Ethnic status is registered on the identification card possessed by citizens of China. In PRC policy, minorities are given certain advantages. For example, minorities have preferred treatment regarding entry to higher studies, and many minority groups are exempted from the one-child policy. ${ }^{1}$ 
A fact of relevance for understanding ethnic differences in income and poverty in China is that its minority population is spatially unevenly distributed. More ethnic minority groups live in rural areas than the majority population, and most are concentrated to the less-developed western part of the country. Even within province level units, ethnic minorities can be concentrated to regions that are less developed. ${ }^{2}$ Furthermore, at the village level there is often segmentation of the population, meaning that persons belonging to one ethnicity dominate in number, ${ }^{3}$

A household's income and poverty situation is influenced by possession of household wealth and what kind of education the household members have. While very little has been written on ethnic gaps in household wealth in China, more has been written on ethnic differences in educational attainment. Evidence surveyed by Hannum et al (2008) and Hannum and Wang (2012) indicate that although minority persons belonging to later birth cohorts are much better educated than older cohorts, most minority groups are at a disadvantage compared to majority persons belonging to the same birth cohort. Such disadvantages can be traced to different, possibly interrelated circumstances. For example, ethnic minorities more frequently live in low-income locations where school quality is often lower than elsewhere. Minority children primarily using their own language face difficulties as instruction in Chinese schools is predominantly in Mandarin. Family circumstances such as low educational attainment of parents and financial difficulties in the household can also contribute to ethnic gaps in length

\footnotetext{
${ }^{1}$ On preferential policies for minorities in education see Teng and Ma (2009). For the recent debate about China's ethnic policy see Sautman (2010).

${ }^{2}$ For example, in Xinjiang Uygur Autonomous region the Han are concentrated to the industrialised and most well-off area in the northeast, while minority people are concentrated to the less developed, agricultural southwestern part of the autonomous region, see for example Cao (2010).

${ }^{3}$ See for example Gustafson and Ding (2009A, p 195)
} 
of education. In addition, length of education is also a result of choices which are influenced by peers and relatives, for example, who typically belong to the same ethnicity. From this follows that ethnic disparities in educational attainment can be transmitted across generations.

Some authors have investigated ethnic differences in earnings and income in urban China, others for rural China. ${ }^{4}$ As the topic here is rural Ningxia we will focus the literature survey on studies on rural China. Some such studies have used data from the China Household Income Project (CHIP). Gustafsson and Li (2003) analysed households living in rural regions of 19 provinces for 1988 and 1995. They found that although average income per capita among minorities increased between the two years, the minority/majority income gap also increased. This was found to be the result of economic growth being spatially unbalanced during the period studied in combination with China's ethnic minorities living primarily in other locations than the majority. In the two provinces Yunnan and Guizhou in the southwest, few ethnic differences in average per capita household were reported. In line with these studies, Gustafson and Ding (2009B) used household panel data from 22 province level units for 2000 to 2002, and reported rural poverty to be more widespread among ethnic minority households than among the majority. However, as majority persons are more numerous, most poor people in rural China belong to the ethnic majority.

The unit of analysis in Gustafsson and Ding (2009A) is the village, and a large survey for 2002 is used for studying household per capita income as well as household per capita wealth. Persons living in minority villages in northeast China were found on average to have a somewhat better economic situation than inhabitants in the average Chinese village, but minority villages in the southwest were clearly faring worse. Among many factors affecting

\footnotetext{
${ }^{4}$ Examples on studies of ethnic differences in the labour market of urban China include Zhang (2008), Maurer-Fazio et al (2010), Zhang (2012) and Hasmath et al (2012).
} 
the economic situation in the village, location was found to be the single most important circumstance negatively affecting the economic situation of a village in the northwest and particularly the southwest.

Some authors have investigated migration by ethnic minorities and compared it with migration of the majority population. ${ }^{5}$ As reasons and destinations for migration differ across time and space, it is not necessarily easy to generalise results from various studies. Furthermore, differences across ethnic minorities might be as large (or perhaps even larger) as differences between the majority and minorities taken as one category. For example, one could hypothesise that minorities having a language of their own and being visibly different from the Han, like the Uighur for example, face larger barriers to migration than the Hui who have the same language as the majority. ${ }^{6}$

One example of a study of ethnic minority migration in China is Iredale et al (2001). Here (Chapter 4), migration rates between minorities and the majority are compared using the 1990 census. The study reports that rates of movement within provinces are relatively similar but lower rates of minority movements across province boundaries are found. Fieldwork in Inner Mongolia (Chapter 5) indicates that generally, migration is seen as a good thing by both individuals and politicians, a positive force for aiding economic development. Also Zhang (2003) paints a positive picture of ethnic minority migration based on experience from Guizhou; many skilled migrants have returned, remittances sent back by rural migrants are significant and urban influences brought back by migrants are not necessarily destructive. Bhalla and Luo (2013) who analysed a sample of minority persons who had migrated to urban

\footnotetext{
${ }^{5}$ For an overview of trends and current issues in internal migration in China see for example Chan (2012).

${ }^{6}$ Maurer-Fazio, M. (2012) conducted a large-scale experiment on how employers respond to internet job board applications of ethnic minorities and the majority. The results indicate the existence of discrimination of persons having names signalling that they are Mongolian, Tibetan and Uighur.
} 
areas of China and kept their rural hukou, reported that in the new location the migrants earned considerably more than at their rural origins.

\section{Context}

According to the fifth national Census 2010, the Hui number 10586078 persons, or 0.79 percent of the total population in China. Hui is the largest of China's ten officially recognised Muslim minorities and is after Zhuang and Manchu the third-largest ethnic minority group in the People's Republic of China. The Hui are spread all over China's 31 province level units. The highest concentration is found in Ningxia Hui autonomous region where 35.4 percent of the population are Hui and 1.4 percent belong to other ethnic minorities (according to published reports from the 2010 Census). An above average concentration of Hui is also found in Gansu, Xinjiang, Henan, Hebei, Shandong and Yunnan. The Hui are at least as urbanized as the Han majority (China's Yearbook of Ethnic Works, 2003).

The Hui are of varied ancestry. It is often claimed that it was during the Ming Dynasty (1360 to 1644 ) that the Huihui (later referred to as Hui) began to emerge as an ethnic group. ${ }^{7}$ The Hui are similar to the Han majority in language and physical appearance. However, as Muslims, they follow Islamic dietary laws and reject the consumption of pork. They also often dress differently from Han as women frequently wear headscarves and men white caps. Some family names also signal that the person most probably belongs to the Hui minority. ${ }^{8}$ Hui typically marry within their ethnic group (See Zang, 2007).

\footnotetext{
${ }^{7}$ For a history of Muslims in northwest China see Lipman (1997).

${ }^{8}$ Some clans in southeast China who are identified as Hui, are Hui due to ancestry only and do not practice Islam as a religion.
} 
Ningxia Hui autonomous region was formed in 1958 and is small compared to most of China's other province level units in terms of area as well as population. With a population of 6.25 million in 2009, only Tibet and Qinghai have smaller populations. However, Ningxia's population is not particularly small when seen from a European perspective. Ningxia has approximately the same number of inhabitants as Bulgaria or Denmark. In 2009, 54 percent of the population in Ningxia lived in a rural area. Measured by indicators such as household income and life expectancy, Ningxia ranks below the median for China. ${ }^{9}$ Natural conditions are in many parts of Ningxia unfavourable for agricultural activities and the government has for some decades carried out resettlement projects (Merkle, 2003). The area used for agricultural production has decreased due to the implementation of national policies aimed at reducing soil erosion by converting farm land on steep slopes into forest and compensating farmers thereafter (see for example Zhang et al, 2008 and Demurger and Wan, 2012). Furthermore, Ningxia is one of China's less-industrialised province level units.

Many rural households in China have sought to improve their economic situation by sending family members as migrants or commuters to places with better employment conditions. Results from our survey show that temporary migration in Ningxia is typically short, as only a minority of migrants have moved out of Ningxia. Migration often takes the form of chain migration. As opposed to many other parts of China, local government officials in rural Ningxia have taken an active role in promoting out-migration of its inhabitants, as the officials' performance can be evaluated based on the number of out-migrants in their jurisdiction.

\footnotetext{
${ }^{9}$ However, provinces in southwest China with a large proportion of ethnic minorities have still lower income levels. See for example Bahall and Qiu (2006, p 58) who focus on poverty and income among ethnic minorities living in southwest China.
} 


\section{Data}

We use data from a socioeconomic survey conducted in 2007 in the Ningxia Hui Autonomous Region by the Ningxia Survey Team of the National Bureau of Statistics on behalf of the Institute of Ethnology and Anthropology, Chinese Academy of Social Sciences. The samples were selected from the larger pool of households surveyed in the region used for official statistical information published each year in the statistical yearbook for Ningxia Autonomous region.

The sampling was drawn as follows: all regularly sampled households in Ningxia living in all five divisions (Yinchuan, Shizuishan, Wuzhong, Guyuan and Zhongwei) of Ningxia were selected. The research team also designed questionnaires for the rural and urban households, respectively. For example, questions on various household assets were collected making it possible to investigate household wealth. In this respect, it followed previous surveys of the China Household Income Project (CHIP) where such questions were asked to households in many provinces of China. ${ }^{10}$ For the households surveyed we received access to information already collected by the survey team. This means, for example, that we can define and measure household income in the same way as the National Bureau of Statistics. Our questionnaire was answered by members in almost all households (99.72 percent). The survey contains 1190 households with 5399 individuals and covers 120 villages. In the sample, 3028 person (57 percent), are Han, 2289 persons (43 percent), are Hui. In addition, a survey on village circumstances was answered by village cadres.

\footnotetext{
${ }^{10}$ See McKinley (1996), Brenner (2001), Gustafsson et al (2006), Zhao and Ding (2008) and Li and Zhao (2008).
} 


\section{Portraying the populations}

/Table 1 about here /

Table 1 provides some basic information on the two ethnic groups derived from our samples. The Hui population has a larger proportion of children than the Han population, and Hui households consistently have a somewhat larger number of members than Han households. This is consistent with Hui females having shorter educations than Han females, as well as the one-child policy on average affecting the Han more stringently than the Hui. We report ethnic as well as gender gaps in length of education among adults. The longest average length of education (7.0 years) is not surprisingly found among Han males, with Hui males coming second (5.6 years), closely followed by Han females (5.3 years), and Hui females coming last with an average of not more than 3.5 years. Our data shows that as many as 45 percent of Hui females are illiterate. Marriages across ethnic groups are very uncommon. Patterns of friendship are also demarcated by ethnic borders. Hui more often than Han have at least one person of the other ethnicity among their three closest friends. While almost all Hui respondents indicate that they are religious, this was only the case among a minority of Han respondents who indicate that they are Buddhists. There is no ethnic difference in the proportion of adult members that are members of the Communist Party (6 percent).

\section{/Table 2/}

We now turn to results on household per capita wealth. We distinguish between some broad types of assets. ${ }^{11}$ We follow McKinley (1993) when defining the user rights to land based on

\footnotetext{
${ }^{11}$ For further details see Zhaon and Ding (2008, p 140-143).
} 
land size and quality and various other assumptions. Housing net of housing debts consists of the market value of private housing after, in a few cases, the subtraction of housing debts. Another component is production assets used in private business activities. Financial assets include term deposits, current account deposits, in a few cases stock shares and bonds and also other financial assets. Consumer goods indicate the value of furniture, TVs, bicycles, etc. Table 2 reports wealth components, average total net household per capita wealth and the Gini coefficient for household net wealth per capita. ${ }^{12}$ This is done for the Han as well as the Hui. Hui households on average own less valued net wealth than Han households and the gap is estimated to be 29 percent. The gap is somewhat larger when it comes to user's right to land and possession of productive assets. In contrast, the ethnic gap in the value of consumer durables is not more than 15 percent and there is actually no statistically significant difference when it comes to financial wealth. The Gini coefficients are similar for the two ethnicities, with a value of 0.44 for Han and 0.45 for Hui. ${ }^{13}$

We have thus found that on average the Hui are not as advantaged as the Han in Ningxia in terms of length of education as well as household wealth. If these were the only circumstances affecting how much income a household earns we would expect to find the Hui to be disadvantaged compared to the Han. And yet, this is not what we report in the next section.

\section{Income and poverty in rural Ningxia}

\footnotetext{
${ }^{12}$ The Gini coefficient is an inequality index that takes values from 0 (no inequality) up to 1.0.

${ }^{13}$ These numbers are higher than reported for rural China as a whole in studies referring to earlier years. Based on CHIP data, Zhao and Ding (2008) report a Gini for household per capita wealth in 1988 of 0.331 , for 1995 of 0.351 and in 2002 of 0.399 .
} 
It is a widely held view in Chinese society that the Hui show great skill in taking advantage of income earning opportunities (see Yang and Ding, 2003, Yang, 2012). This can be due to necessity as reported in the previous section, as they own fewer user rights to land and productive assets and they have shorter educations than the Han. One can claim that over the course of generations, by living in other villages the Hui have acquired a somewhat different lifestyle than the Han. This can express itself in their being more involved in non-farm activities including migration than the Han. The Hui have a reputation for often being involved in private business or working for a wage (see Liu and $\mathrm{Li}, 2011$ ). Field visits in rural Ningxia by one of the authors show that remarkably often the Hui migration is organised by local township cadres. For example township level government had made an agreement with a work unit in the eastern part of China to recruit migrant. The local cadres down to the administrative village level have as a task to promote outmigration.

One way to investigate whether the Hui have a better ability to take advantage of income generating opportunities is to estimate income functions that include a number of variables which are likely to affect household income. In the specification, a dummy for Hui ethnicity is also included and we expect that the coefficient will be positive. The outcome of this exercise is shown in Table 3. Explanatory variables include average number of years of education of household members in work active ages measured in years, and average age of adult household members and household size measured as number of persons. We also include the square of each of the three variables in order to allow for possible non-linear effects. Further we include as explanatory variables the percentage of household members that are of work active ages and the percentage of the working members that are members of China's Communist Party. We also include the percentage of family members that are in poor health and the contracted farm land measured in mu. Estimates are shown in Table 3. 
/Table 3 about here/

The parameter of main interest in Table 3, the coefficient for Hui ethnicity in the equation for household income, is positive and estimated with high t- statistics. Thus given a number of income generating variables, Hui are earning more than Han. From the estimates in Table 3 we also learn that household per capita income is positively affected by years of education among adult members but at a decreasing rate, and negatively affected by household size at a decreasing rate. Furthermore, per capita household income is positively affected by the percentage of household members of working age and negatively affected by the percentage of household members in poor health. The amount of contracted farm land has a positive effect on household income.

/Table 4 about here/

One possible reason for the positive coefficient for the Hui dummy in Table 3 is that the Hui are more involved in migration. This can be seen in Table 4 which also shows that in rural Ningxia migration is typically a male activity. As many as 46 percent of Hui males were involved in migration in 2006, while the corresponding proportion among Han males was 35 percent. Hui migrants earn on average less than Han migrants. On average, migration lasted for about half a year. Data from our survey and from Ningxia Statistical Bureau indicate that many migrants work in construction. Often people migrate over a short distance. Out of province migration is typically to neighbouring provinces. Note that the information in Table 4 indicates that most migrant income is sent home. 
We are interested in better understanding to what extent migration in Ningxia is influenced by low village income and by ethnicity. We have therefore specified and estimated probit models for the subsample of adult household members who are in work active ages. As can be seen in Table 5, we relate the event of having migrated during 2006 to village characteristics (as obtained from the survey to village cadre) in Specification 1, alternatively to household and individual characteristics in Specification 2. Specification 3, on which our comments are concentrated, includes characteristics at the village, individual as well as household level. ${ }^{14}$

/Table 5 about here/

The pattern we find is a very clear negative relation between mean income of the village and the probability of migrating. In other words, people migrate because they live in a poor village. ${ }^{15}$ However, as migrants bring home income, it follows that migration has an income redistributing function across villages. Turning to individual characteristics used in the specifications, we find that age negatively affects the probability of migrating as does being female. Two household variables are found to affect the probability of migrating. Per capita land has a negative effect as does the number of children in the household. Having access to a significant amount of land as well as having children makes people less likely to migrate. Table 5 also shows that Hui ethnicity (at the village level in Specification 1 and at the individual level in Specification 3) has an independent positive effect on the probability to migrate.

\footnotetext{
${ }^{14}$ As the variables, proportion of Hui in the village and the dummy indicating being Hui, are strongly correlated, we drop the former in the third specification.

${ }^{15}$ This is consistent with results from, for example. Gustafsson and Ding (2009A).
} 
/Figure 1 about here/

In Figure 1 we use Specification 3 reported in Table 5 to predict the probability of migrating for persons with different characteristics. For a base person (A), a man aged 23 and living in a village belonging to the lowest decile according to per capita income, the probability of migrating is predicted to be 52 percent. The corresponding probability is 36 percent if the village has a mean income placing it in the top decile (the second panel), that is to say 16 percent lower. The large importance of age is evident, as changing the age of the base person to 40 (case E) makes the probability for migration to go down from 52 percent to 24 percent, a reduction of 28 percent. This change is almost identical to the probability obtained for being aged 23 and female (B). Changing the amount of land the household has access to (F and G) for the base individual leads to a variation in migration probability of ten percentage units. From Figure 1 we can also learn that compared to the variations in the variables village income, age and gender, the importance of number of children in the household (Cases H, I, J and $\mathrm{K}$ ) is of lesser importance.

/Table 6 about here/

Have the higher migration activities among the Hui partly triggered by low village income in combination with a higher frequency of out of farm work fully compensated the disadvantage of being less educated and owning less valuable land when it comes to earning an income? In Table 6 we compare income components per capita, average household income per capita and income inequality among Hui and Han in rural Ningxia. Interestingly enough, we find that average total income per capita is estimated to be identical among Hui and Han. True, Hui have agriculture income amounting to only 65 percent of the agricultural income for Han. 
However, this is fully compensated for by higher income from wages and business as well as non-agriculture income. Much of this is due to higher migration activities and other non-farm activities. $^{16}$

/Table 7 about here/

Table 6 also shows that income inequality among Hui measured by the Gini coefficient is larger than among Han (0.45 to be compared with 0.36$).{ }^{17}$ As we will see in Table 7 this is consistent with non-agricultural income constituting a larger fraction of total income among Hui than among Han, and non-agriculture income being more concentrated to high total income. Furthermore, the concentration of non-agriculture income to those with a high income is particularly high among Hui. Table 7 shows results from decomposing the Gini coefficient by income sources for each of the two ethnicities. The Gini for total net income is a weighted sum of the concentration coefficients for each income component. The relative shares of each income component are the weights. The Concentration coefficient indicates the association between the income component and total net income and can take values from - 1 to +1 . The higher the value of the concentration coefficient, the stronger the particular income component concentrated to high income units. Table 7 shows that 22 percent of total income among Hui came from non-agricultural income, having a concentration coefficient as high as 0.70 . The last column shows that as much as 35 percent of the Gini value for Hui can be attributed to non-agricultural income. The corresponding number for the Han majority is not more than 14 percent (of a lower Gini).

\footnotetext{
${ }^{16}$ Our data does not allow us to isolate the importance of remittances from migrants as a separate income component.

${ }^{17}$ The Gini for Hui in rural Ningxia appears as high also when compared to what has previously been reported for rural China as a whole. Based on the China Household Income Project (CHIP) Gustafsson et al (2008) report the following Ginis: 0.325 in $1988,0.364$ for 1995 and 0.365 for 2002.
} 
/Figure 2 about here/

Does the higher income inequality among Hui, in combination with the identical mean incomes lead to Hui being more likely than Han to be poor? The answer to this question is "no" as long as we apply poverty lines in use by the National Bureau of Statistics for the year under investigation. In Figure 2 we show Cumulative Density Functions for household per capita income of Hui and Han individuals for the lower range of the distributions. That is, the horizontal axis shows household per capita income and the vertical axis cumulative proportion of individuals. In the figure we have also drawn the poverty line at 693 Yuan per person and year (which was the poverty line NBS applied for rural China in 2006), as well as the low income line of 958 Yuan per year also applied by NBS the same year. The estimated proportion of individuals falling under the poverty line set to 693 Yuan per year is 4.9 percent for Hui and 4.5 percent for Han. The proportion of Hui falling under the low income line is estimated to 12.1 percent and 10.3 percent among Han. However, note that at higher income levels, the graph for Hui is higher than the graph for Han. This means that for higher poverty lines, Hui would be deemed to be more poverty prone than Han. ${ }^{18}$

\section{Conclusions}

In this study we have investigated income and poverty of Hui and Han persons living in rural Ningxia Hui autonomous region in the People's Republic of China. The Hui ethnic group is the most numerous Muslim minority in China and makes up roughly one-third of the population of Ningxia. We have used a household survey collected for 2006. The data shows that intermarriage is rather uncommon between people belonging to the two ethnicities. Rural

\footnotetext{
${ }^{18}$ In 2008 the National Bureau of Statistics introduced a poverty line for rural China set to RMB 1196 per person and year and in 2011 a poverty line set to 2300 Yuan per person and year was introduced.
} 
Hui persons live to a large extent in other (poorer) villages than Han persons and both ethnicities socialise mainly with persons of the same ethnicity. In this sense we are talking about two different populations among which Hui live in households that on average have a larger number of members than Han households.

We have reported that in rural Ningxia adult Hui persons on average have shorter educations than Han of the same gender and that women have shorter educations than men. We have also reported an ethnic gap in average per capita household wealth amounting to 29 percent disfavouring the Hui. The gap is even larger regarding user rights to land and productive assets. Based on the lower educational attainment and ownership of lesser-valued assets, one would expect that Hui in rural Ningxia would be disadvantaged compared to Han in terms of mean disposable per capita income and in rates of poverty. However, this is not what we have reported. Average household per capita income is the same and one cannot talk about an ethnic gap in poverty as long as assessment is made according to the poverty line the National Bureau of Statistics applied for rural China in 2006.

The explanation for this paradox is that the rural Hui to a larger extent than the rural Han are involved in non-farm work that includes migration. According to our data, as many as almost one in two male Hui in Ningxia migrated in 2006 and they brought home substantial amounts of income. Results from estimated models indicate that a low village income is one but not the only factor behind the higher probability of Hui to migrate. This analysis has also illustrated that the probability of migrating is particularly high for young Hui males living in a lowincome village in households with little land and no dependent children. We have shown that Hui households earn more in non-agricultural income than Han and such incomes are disproportionately concentrated to those better off. The latter is an important reason why the 
distribution of income among Hui is found to be rather unequal, more unequal than among Han.

To round off, the main result of this paper has been to find a non-existent ethnic income gap and poverty gap in rural areas of Ningxia. It will be an important task for future research to investigate whether different or similar results can be found for urban Ningxia as well as for Tibet, Xinjiang, Guangxi, and Inner Mongolia - the four other autonomous regions of China with large minority groups. One final comment: for readers familiar with the present situation in northern Europe with Muslim populations tending to have considerably lower incomes than the majority and to be more poverty prone, our results can provoke further thought. We have namely found that in a rural region where a Muslim minority has lived for generations, there is no sign of an income or poverty gap despite the minority having shorter educations and owning fewer assets. 


\section{References}

Basant, R. and Shariff, A. (eds) (2010) Oxford Handbook of Muslims in India. Empirical and Policy Perspectives, New Delhi: Oxford University Press.

Bhalla, A.S. and Luo, D. (2013) Poverty and Exclusion of Minorities in China and India, Basingstoke, Palgrave Macmillan.

Bhalla, A.S. and Qiu, S. (2006) Poverty and Inequality among Chinese Minorities, London and New York: Routledge.

Brenner, M. (2001) "Reexamining the Distribution of Wealth in Rural China", in Riskin, C., Zhao, R. and Li, S. (1995) China's Retreat from Equality. Income Distribution and Economic Transition, Armonk, N. Y. M.E. Sharpe.

Buechel, F. and Frick, J. (2004) "Immigrants in UK and West Germany - Relative income position, income portfolio and redistributive effects", Journal of Population Economics, 17, $553-581$.

Chan, K. W. (2012) "Migration and Development in China: Trends, Geography and Current Issues", Migration and Development, 1, 187-205.

Chao, H. (2010) "Urban-Rural Income Disparity and Urbanization: What is the Role of Spatial Distribution of Ethnic Groups? A Case Study of Xinjiang Uygur Autonomous Region in Western China", Regional Studies, 44, 965-982. 
Demurger, S. and Wan, H. (2012) "Payments for Ecological Restoration and Internal Migration in China: The Sloping Land Conversion Program in Ningxia”, IZA Journal of

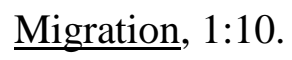

Georgladis, A. and Manning, A. (2011) "Change and Continuity among Minority Communities in Britain", Journal of Population Economics, 24, 541-568.

Gustafsson, B. and Li, S. (2003) "The Ethnic Minority - Majority Income Gap during Transition", Economic Development and Cultural Change, 51, 805-822.

Gustafsson, B., Li, S. and Wei, Z. (2006), "The Distribution of Wealth in Urban China and in China as a whole in 1995", Review of Income and Wealth, 52, 173-188.

Gustafsson, B., Li, S., Sicular, T. and Yue, X. (2008) "Income Inequality and Spatial Differences in China, 1988, 1995 and 2002" in Gustafsson, B., Li, S. and Sicular, T. (Eds) Inequality and Public Policy in China, Cambridge:, Cambridge University Press.

Gustafsson, B. and Ding S. (2009A) “Villages where China's Ethnic Minorities Live”, China Economic Review, 20, 193-207.

Gustafsson, B. and Ding, S. (2009B) "Temporary and Persistent Poverty among Ethnic Minorities and the Majority in Rural China", Review of Income and Wealth, 55, Special issue, 588-606. 
Hannum, E., Behrman, J. Wang, M and Liu, J. (2008) "Education in the Reform Era" in Brandt, L. and Rawski, T. (Eds) China's Great Economic Transformation, Cambridge: Cambridge University Press.

Hannum, E. and Wang, M. (2012) “China. A Case Study in Rapid Poverty Reduction” in Hall, G. and Patrinos, H. (Eds) Indigenous Peoples, Poverty and Development. Cambridge: Cambridge University Press.

Hasmath, R., Ho, B. and Liu, E. (2012) "Ethnic Minority Disadvantage in China's Labor Market?", China Growth Centre at St Edmund Hall, University of Oxford, Discussion Papers Series No 16.

Iredale, R. Bilik, N., Su, W. (Eds) (2001) Contemporary Minority Migration, Education and Ethnicity in China, Cheltenham UK and Northampton MA, USA: Edward Elgar.

Li, S. and Zhao, R. (2008) Changes in the Distribution of Wealth in China, 1995-2002" in Davies, J. Editor (2008) Personal Wealth from a Global Perspective, Oxford: Oxford University Press.

Lipman, J. (1997) Familiar Strangers. A History of Muslims in Northwest China, Seattle and London: University of Washington Press. 
Liu C. and Li Y. (2011) "Investigation Report of Rural Labor Employment Status in Ningxia Hui Autonomous Region" Journal of Southwest University for Nationalities (Humanities and Social Sciences), No.9, pp128-132, (In Chinese).

Maurer-Fazio, M., Hughes, J. and Zhang, D. (2010) “A Comparison and Decomposition of Reform-era Labor Force Participation Rates of China's Ethnic Minorities and Han Majority”, International Journal of Manpower, 31, 138-162.

Maurer-Fazio, M (2012) "Ethnic Discrimination in China's Internet Job Board Labor Market", IZA Journal of Migration, 1, 12.

McKinley. T. (1996) The Distribution of Wealth in Rural China, Armonk, N.Y., M.E. Sharpe.

Merkle, R. (2003) “Ningxia’s Third Road to Rural Development: Resettlement Schemes as a Last Means to Poverty Reduction?”, Journal of Peasant Studies, 30, 160-191.

Sautman, B. (2010) "Scaling Back Minority Rights? The debate about China's Ethnic Policies”, Stanford Journal of International Law, 46, 51 - 120.

Teng, W. and Ma, X. (2009) "Preferential Policies for Ethnic Minorities and Educational Equality in Higher Education in China", in Zhou, M. and Maxwell Hill, A. (Eds) Affirmative Action in China and the U.S.: A Dialogue on Inequality and Minority Education, New York: Pelgrave Macmillan. 
Yang H., (2012), “The Changes of Hui's Society Under the Urbanization Background”, Social Sciences in Ningxia, No.1, 63-68 (In Chinese).

Yang S and Ding H. (2003) Ethnography of China", Beijing: Minzu University of China Press ( in Chinese).

Zang, X. (2007) Ethnicity and Urban Life in China. A comparative study of Hui Muslims and

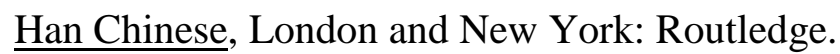

Zang, X. (2008) "Market Reform and Han-Muslim Variation in Employment in the Chinese State Sector in a Chinese City", World Development, 36, 2341-2352.

Zang, X. (2012) “Age and the Cost of Being Uyghurs in Urumchi”, China Quarterly, vol 210, 419- 434.

Zhang J ( 2003) "Ethnic Minority Labour Out-migration from Guizhou Province and their Impacts on Sending Areas" in Iredale, R., Bilik, N. and Guo, F. (Eds) China's Minorities on the Move, Armonk, New York: M.E. Sharpe.

Zhang, L., Tu, Q., Mol, P.J. (2008) "Paying for Environmental Services: The Sloping Land Conversion Program in Ningxia Autonomous Region of China", China \& World Economy, $16,66-82$. 
Zhao, R. and Ding, S. (2008) "The Distribution of Wealth in China" in Gustafsson, B., Li, S. and Sicular, T. (Eds) Inequality and Public Policy in China, Cambridge:, Cambridge University Press. 
Table1

Descriptive statistics on Han and Hui persons in urban and rural Ningxia 2006

\begin{tabular}{||l|l|l||}
\hline \multicolumn{1}{|l||}{} & HAN & HUI \\
\hline Proportion under age 18. Percent & 26.8 & 34.2 \\
\hline Average age of individual (years) & 32.3 & 28.5 \\
\hline $\begin{array}{l}\text { Average household size } \\
\text { persons) }\end{array}$ & 4.35 & 4.90 \\
\hline Adult males average years of schooling & 6.99 & 5.58 \\
\hline Adult females average years of schooling & 5.28 & 3.51 \\
\hline Adult males illiterate, percent & 11 & 18 \\
\hline Adult females illiterate, percent & 39 & 45 \\
\hline Percentage adults that are married & 75.9 & 80.2 \\
\hline Percentage endogamy among couples & 99.7 & 99.8 \\
\hline $\begin{array}{l}\text { Percentage of adults indicating that at least one of three best friends belong to } \\
\text { another ethnic group }\end{array}$ & 12.4 & 28.1 \\
\hline $\begin{array}{l}\text { Percentage of adult respondents that indicate they are religious (Buddhism, } \\
\text { Islam) }\end{array}$ & 22.6 & 100.0 \\
\hline Percent of adults that are CPC members & 5.9 & 5.5 \\
\hline Number of observations & 2268 & 1486 \\
\hline Mean administration village household income RMB & 3049 & 2601 \\
\hline
\end{tabular}

Note: There is a large non-response in the question on ethnicity among three best friends as answers were obtained by 555 / 556 Han / Hui respondents. The question of endogamy was answered by 1715 / 1176 Han/Hui. The question on religion was answered by $2721 / 2050$ Han/Hui.

A person is considered to be an adult at age 18. Source: Authors' calculation from Socioeconomic Survey of Ningxia 2006. 
Table 2

Household Per capita Wealth among Han and Hui households in rural and urban Ningxia: Components, mean value and Gini coefficients 2006.

Household is unit of analysis

\begin{tabular}{||l|c|l|l||}
\hline \hline WEALTH COMPONENT, ETC & $\begin{array}{l}\text { HAN } \\
\text { YUAN }\end{array}$ & $\begin{array}{l}\text { HUI } \\
\text { YUAN }\end{array}$ & HUI AS PERCENT OF HAN \\
\hline User rights to land & 11374 & 7330 & $64^{* * *}$ \\
\hline Housing net of housing debts & 5338 & 4260 & $80^{* * *}$ \\
\hline Productive assets & 3746 & 2464 & $66^{* * *}$ \\
\hline Financial assets & 2391 & 2029 & 85 \\
\hline Consumer goods & 1522 & 1305 & $86^{* * *}$ \\
\hline Debts & 1518 & 1256 & 83 \\
\hline Total average net wealth & 22853 & 16131 & $71^{* * *}$ \\
\hline Gini coefficient for total household wealth & 0.440 & 0.451 & \\
\hline Average household size & 4.35 & 4.90 & \\
\hline Number of observations & 716 & 467 & \\
\hline \hline
\end{tabular}

Note: There is no question "Other assets in household" in the rural questionnaire.

${ }^{* * * *}$ Indicates that the means for Han and Hui are statistically different at the 1 percent level.

${ }^{* * *}$ Indicates that the means for Han and Hui are statistically different at the 5 percent level.

* Indicates that the means for Han and Hui are statistically different at the 10 percent level

Source: Authors' estimates from Socioeconomic Survey of Ningxia 2006. 
Table 3

\section{Income functions for rural Ningxia}

\begin{tabular}{||l|l|l||}
\hline \multicolumn{2}{|l|}{ Household income per capita } \\
\hline & Coefficient & T-value \\
\hline Education years & & \\
\hline Education years squared & $183.43^{* * *}$ & 4.68 \\
\hline Age & $-9.556^{* * *}$ & -3.0 \\
\hline Age squared & 21.305 & 1.23 \\
\hline Household size & -0.203 & -1.05 \\
\hline Household size squared & $-2373.61^{* * *}$ & -17.41 \\
\hline Percent of household members of working age & $214.055^{* * *}$ & 18.76 \\
\hline Percentage of working members that belong to the Party & $7.623^{* * *}$ & 2.58 \\
\hline Percent of family members that are in poor health & 5.410 & 1.37 \\
\hline Contracted farm land per capita (Mu) & $-13.809^{* * *}$ & -4.76 \\
\hline Hui dummy & $0.113 * * *$ & 21.62 \\
\hline Constant & $622.0^{* * *}$ & 5.59 \\
\hline Adj R-squared & $6560.925^{* * *}$ & 9.40 \\
\hline Observations & 0.2297 & \\
\hline \hline
\end{tabular}

Note: The population studied is persons at least 18 years of age.

*** indicates statistical significance at least the 1 percent level.

$* *$ indicate statistical significance at the 5 percent level.

*indicates statistical significance at the 10 percent level.

Source: Authors' estimate from Socioeconomic Survey of Ningxia 2006. 
Table 4

Migration among Hui and Han in rural Ningxia 2006

\begin{tabular}{||l|l|l|l|l|l|l||}
\hline \multicolumn{2}{|l|}{} & \multicolumn{2}{l|}{ HAN } & \multicolumn{2}{l|}{ HUI } & \multicolumn{2}{l||}{$\begin{array}{l}\text { T-TEST OF EQUALITY } \\
\text { BETWEEN HAN AND HUI }\end{array}$} \\
\hline & Males & Females & Males & Females & Males & Females \\
\hline $\begin{array}{l}\text { Proportion with migrant } \\
\text { experience during 2006 } \\
\text { Among people 16-55/60 }\end{array}$ & 34.7 & 11.1 & 46.2 & 14.2 & $5.00^{* * *}$ & $1.72^{*}$ \\
\hline $\begin{array}{l}\text { Average duration of } \\
\text { migration in 2006 } \\
\text { (months) }\end{array}$ & 7.0 & 7.5 & 6.2 & 5.9 & $3.12^{* * *}$ & $3.1^{* * *}$ \\
\hline $\begin{array}{l}\text { Income of migration } \\
\text { work in 2006 (among } \\
\text { migrants) RMB }\end{array}$ & 6774 & 5581 & 5779 & 3843 & $3.39 * * *$ & $4.30^{* * * *}$ \\
\hline $\begin{array}{l}\text { Percent of migrant } \\
\text { income remitted }\end{array}$ & 69.5 & 57.0 & 71.8 & 68.5 & 1.15 & $2.60^{* * * *}$ \\
\hline
\end{tabular}

Source: Authors' calculation from Socioeconomic Survey of Ningxia 2006. 
Table 5

Determinants of migration in rural Ningxia 2006.

Probit model

\begin{tabular}{||l|l|l|l|l|l|l||}
\hline & $\mathrm{dy} / \mathrm{dx}$ & $\mathrm{Z}$ value & $\mathrm{dy} / \mathrm{dx}$ & $\mathrm{Z}$ value & $\mathrm{dy} / \mathrm{dx}$ & $\mathrm{Z}$ value \\
\hline $\begin{array}{l}\text { Mean household } \\
\text { income in a village }\end{array}$ & $-0.00003^{* * *}$ & -4.58 & & & $-0.00005^{* * *}$ & -5.73 \\
\hline $\begin{array}{l}\text { Proportion migrants } \\
\text { in a village }\end{array}$ & 0.0191 & 0.827 & & & 0.0234 & 0.29 \\
\hline $\begin{array}{l}\text { Proportion Hui } \\
\text { in a village }\end{array}$ & $0.0509^{* * *}$ & 2.56 & & & & \\
\hline Age of person & & & $-0.0073^{* * *}$ & -10.25 & $-0.0068^{* * *}$ & -9.39 \\
\hline Education years & & & $-0.0079^{* * *}$ & 0.003 & 0.0040 & -1.48 \\
\hline Female & & & $-0.2864 * *$ & -18.87 & $-0.2804^{* * *}$ & -18.41 \\
\hline Per capita land & & & -0.0024 & -1.28 & $-0.0074 * * *$ & -3.53 \\
\hline Number of children & & & $-0.0095^{*}$ & -1.82 & $-0.0152^{* * *}$ & -2.85 \\
\hline Number of elderly & & & -0.0274 & 1.47 & -0.0243 & -1.30 \\
\hline Hui & & & $0.0609^{* * *}$ & 3.56 & $0.0447 * * *$ & 2.58 \\
\hline Number of Obs. & 2540 & & 2540 & & 2540 & \\
\hline \hline
\end{tabular}

Note: The observations are individuals aged 16-55 for females and 16-60 for males.

The dependent variable is: whether the household member in 2006 migrated (1) or not (0).

Source: Authors' estimates from Socioeconomic Survey of Ningxia 2006. 


\section{Table 6}

Income components and total per capita income among Han and Hui in rural Ningxia. Yuan 2006. Individuals are unit of analysis.

\begin{tabular}{||l|l|l|l||}
\hline & HAN & HUI & $\begin{array}{l}\text { HUI AS PERCENT } \\
\text { OF HAN }\end{array}$ \\
\hline Farm net income & 1855.36 & 1207.96 & $65^{* * * *}$ \\
\hline $\begin{array}{l}\text { Wages and business } \\
\text { income }\end{array}$ & 697.40 & 985.26 & $244^{* * * *}$ \\
\hline $\begin{array}{l}\text { Non-agricultural } \\
\text { activity income }\end{array}$ & 314.78 & 766.83 & 40 \\
\hline $\begin{array}{l}\text { Benefits of renting } \\
\text { out land, etc }\end{array}$ & 28.40 & 11.43 & 89 \\
\hline $\begin{array}{l}\text { Imputed rents of } \\
\text { owner-occupied } \\
\text { housing }\end{array}$ & 105.22 & 93.61 & $51^{* * *}$ \\
\hline Transfer income of & 200.22 & 101.48 & 92 \\
\hline Other income & 281.37 & 259.65 & 99 \\
\hline Total net income & 3482.76 & 3434.96 & \\
\hline Gini coefficient & 0.3616 & 467 & \\
\hline $\begin{array}{l}\text { Number } \\
\text { households }\end{array}$ & 3080 & 2297 & \\
\hline $\begin{array}{l}\text { Number } \\
\text { individuals }\end{array}$ & & \\
\hline
\end{tabular}

\footnotetext{
**** Indicates that the means for Han and Hui are statistically different at the 1 percent level.

** Indicates that the means for Han and Hui are statistically different at the 5 percent level

* Indicates that the means for Han and Hui are statistically different at the 10 percent level

Source: Authors' estimates from Socioeconomic Survey of Ningxia 2006.
} 
Table 7

Decomposing the Gini coefficient for household per capita income by income components for Hui and Han in rural Ningxia

\begin{tabular}{|c|c|c|c|c|}
\hline & GINI & $\begin{array}{l}\text { PROPORTION } \\
(\%)\end{array}$ & $\begin{array}{l}\text { CONCENTRATION } \\
\text { RATIO }\end{array}$ & $\begin{array}{lr}\text { CONTRIBUTION } & \text { TO } \\
\text { GINI IN TOTAL NET } \\
\text { INCOME. PERCENT }\end{array}$ \\
\hline \multicolumn{5}{|r|}{ (2) } \\
\hline $\begin{array}{l}\text { Total net } \\
\text { income }\end{array}$ & 0.3616 & 100 & 0.3616 & 100 \\
\hline $\begin{array}{ll}\text { Farm net } \\
\text { income }\end{array}$ & & 53.27 & 0.3747 & 55.20 \\
\hline $\begin{array}{l}\text { Wages and } \\
\text { business income }\end{array}$ & & 20.02 & 0.2841 & 15.73 \\
\hline $\begin{array}{l}\text { Non- } \\
\text { agricultural } \\
\text { activity income }\end{array}$ & & 9.04 & 0.5698 & 14.24 \\
\hline $\begin{array}{l}\text { Benefits of } \\
\text { renting out land, } \\
\text { etc }\end{array}$ & & 0.82 & 0.6632 & 1.50 \\
\hline $\begin{array}{l}\text { Imputed rents of } \\
\text { owner-occupied } \\
\text { housing }\end{array}$ & & 3.02 & 0.4795 & 4.00 \\
\hline Transfer income & & 5.75 & 0.0055 & 0.09 \\
\hline Other income & & 8.08 & 0.4136 & 9.24 \\
\hline \multicolumn{5}{|l|}{ Hui } \\
\hline $\begin{array}{ll}\begin{array}{l}\text { Total net } \\
\text { income }\end{array} & \\
\end{array}$ & 0.4490 & 100 & 0.4490 & 100 \\
\hline $\begin{array}{ll}\text { Farm net } \\
\text { income }\end{array}$ & & 35.16 & 0.3859 & 30.22 \\
\hline $\begin{array}{l}\text { Wages and } \\
\text { business income }\end{array}$ & & 28.68 & 0.3429 & 21.90 \\
\hline $\begin{array}{l}\text { Non- } \\
\text { agricultural } \\
\text { activity income }\end{array}$ & & 22.32 & 0.7038 & 34.99 \\
\hline $\begin{array}{l}\text { Benefits of } \\
\text { renting out land, } \\
\text { etc }\end{array}$ & & 0.33 & 0.3719 & 0.27 \\
\hline $\begin{array}{l}\text { Imputed rents of } \\
\text { owner-occupied } \\
\text { housing }\end{array}$ & & 3.22 & 0.5554 & 3.98 \\
\hline Transfer income & & 2.73 & 0.0001 & 0.001 \\
\hline Other income & & 7.56 & 0.5192 & 8.73 \\
\hline
\end{tabular}

Source: Authors' estimates from Socioeconomic Survey of Ningxia 2006. 
Figure 1

Predicted probabilities of migrating for individuals living in villages with different income levels.

Panel A: Village with average income.

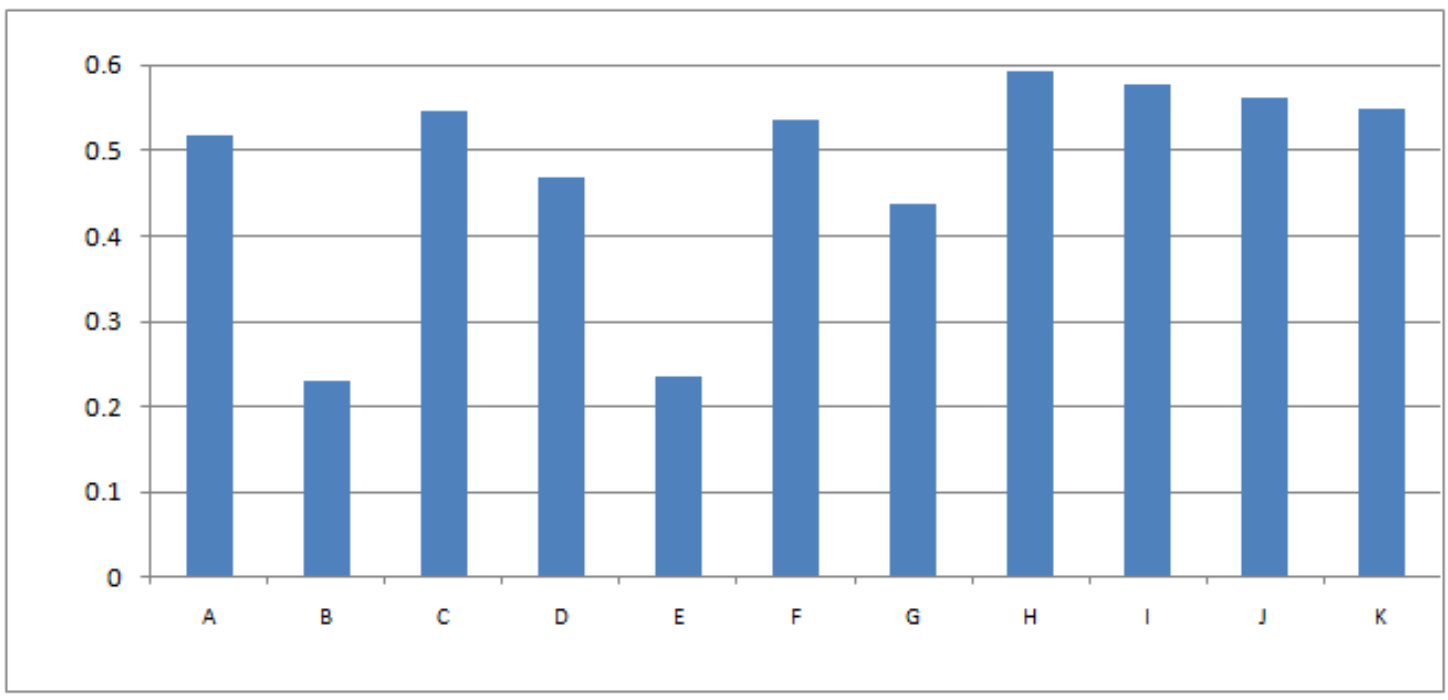

Panel B Village with an income at the mean value of the lowest decile of village incomes

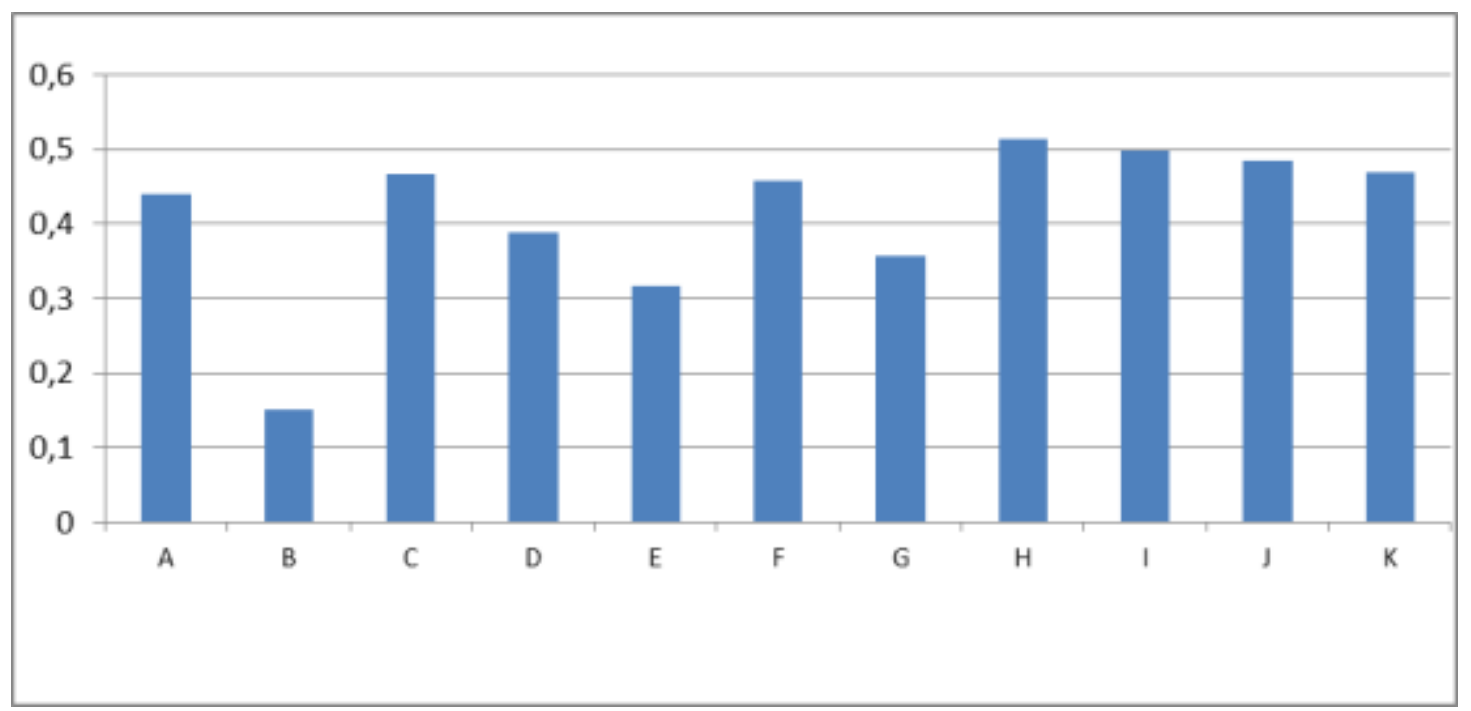

Panel C Village with an income at the mean value of the lowest decile of village incomes 


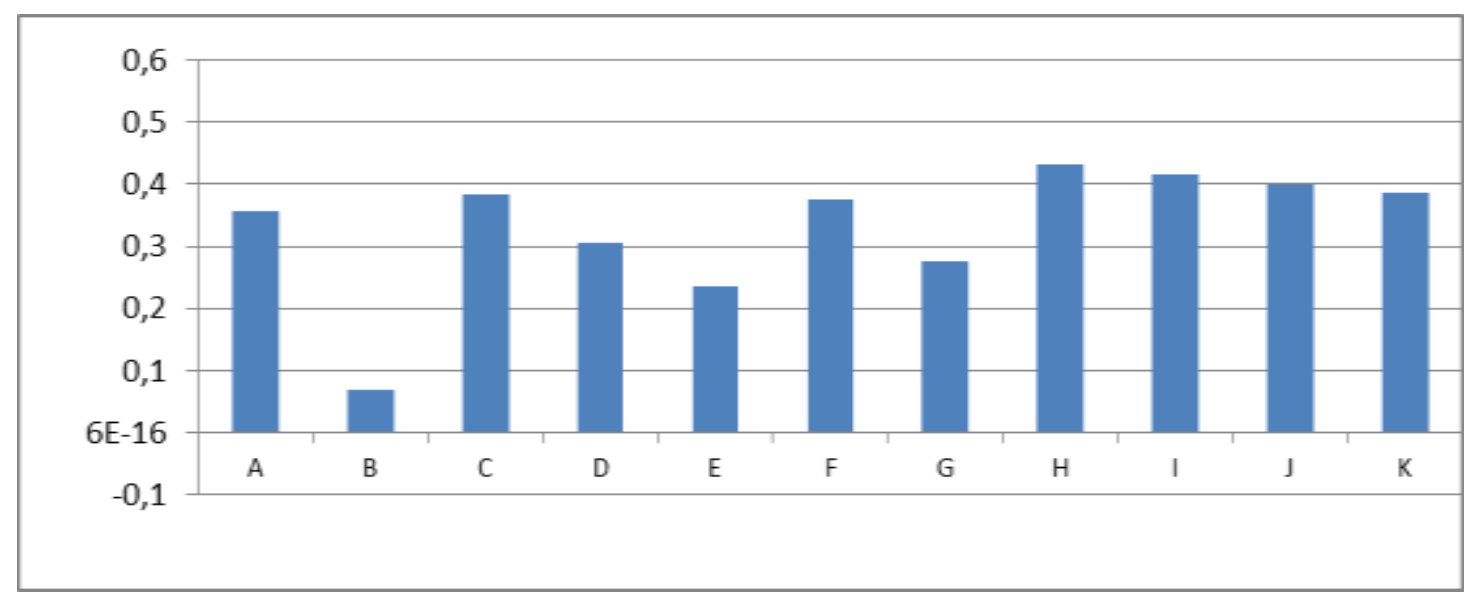

Source: Table 5.

Explanations:

A is a male aged 23 with a middle level education living in a household having per capita land at the average in the sample. There are four children in the household.

$\mathrm{B}$ is a female with all other characteristics same as A.

C. has all characteristics of person A but aged 19.

D. has all characteristics of person A but aged 30 .

E. has all characteristics of person A but aged 40 .

F. has all characteristics of person A but lives in a household with per capita land at the average of the lowest decile in the sample

G. has all characteristics of person A but lives in a household with per capita land at the average of the highest decile in the sample

H. has all characteristics of person A but lives in a household with no children.

I. has all characteristics of person A but lives in a household with one child.

J. has all characteristics of person A but lives in a household with two children.

K. has all characteristics of person A but lives in a household with three children. 
Figure 2.

Cumulative density functions for Han and Hui in rural Ningxia 2006.

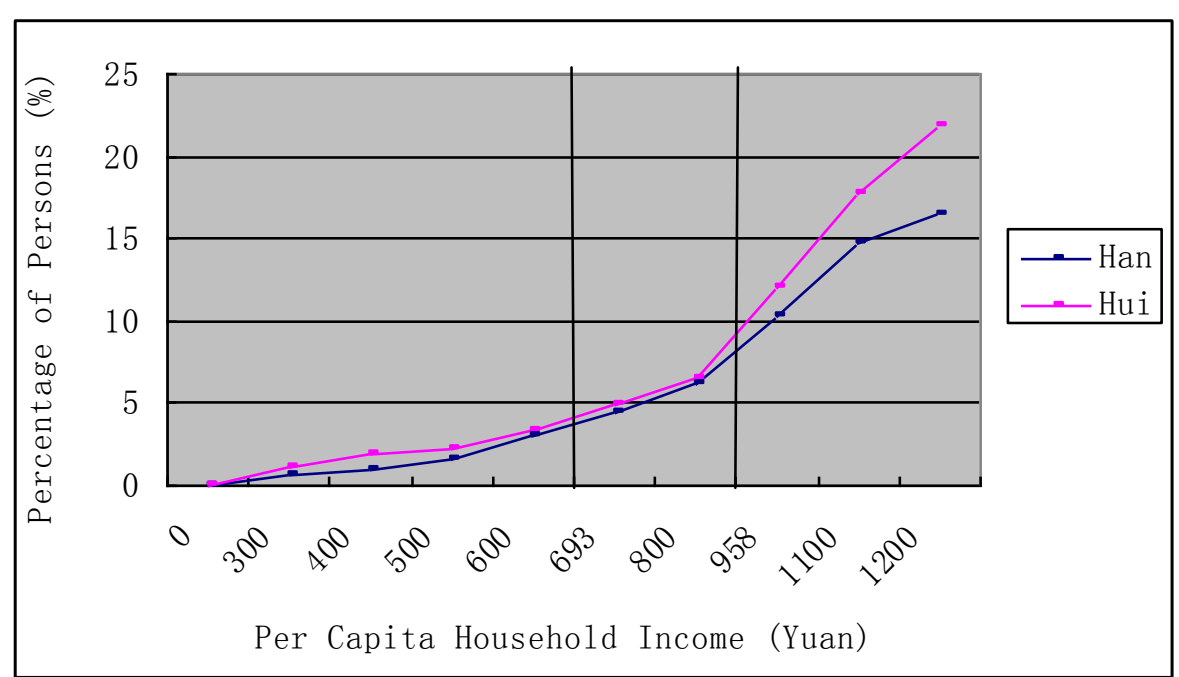

Note: 693 Yuan per capita household income is the poverty line of rural China, 694 to 958 Yuan per capita household income is the low-income line in rural China in 2006 published by NBS.

Source: Authors' estimates from Socioeconomic Survey of Ningxia 2006. 